\section{New sales tax hits science}

\section{Tokyo}

JAPAN's controversial new sales tax, which came into effect last week, has not only placed an additional burden on Japan's consumers but has also pushed up the costs of scientific research. The budgets for the science-related ministries have been increased over the past few months to cover some of the costs of the new tax, but universities and research institutes will still find themselves worse off.

The sales tax marks the most sweeping reform of Japan's tax system since the Second World War and has met almost universal opposition. Although set at a low overall rate of 3 per cent, the tax covers almost all forms of 'consumption'. Books, food, transportation, rent and even the costs of childbirth and tombstones are taxed. Scientific research is no exception.

Although the tax takes up only a small percentage of ministerial budgets, it does constitute a significant proportion of the increase in outlay for science between the fiscal years 1988 and 1989 - about 20 per cent, or $¥ 5,900$ million ( $\$ 45$ million), in the case of the Science and Technology Agency.

The tax is levied on the purchase of equipment, books and journals and also adds significantly to the cost of construction of new facilities. Although the various science-related ministries have made upward revisions in their budgets to cover the tax, some of the burden will inevitably have to be borne by the universities and research institutes.

For example, although the Ministry of Education, Science and Culture has raised the budget for fiscal year 1989 for grantsin-aid of research to cover the increased costs of equipment, the value of multi-year grants awarded before implementation of the tax (for example, the 'special distinguished grants' which run for 3-5 years) will remain unchanged.

The new tax has helped to make Noboru Takeshita the most unpopular prime minister in the post-war era. The latest polls show that less than 10 per cent of the public support his administration. And revelations last week that Takeshita received almost $¥ 100$ million $(\$ 760,000)$ in donations from the scandal-ridden Recruit company in the run-up to his election as head of the ruling Liberal Democratic Party (LDP) have further weakened his position.

Calls for Takeshita's resignation are growing within the LDP and he may not be able to survive in office for longer than a few more months. Under a new leader, the sales tax could be revised, but as it has taken the LDP ten years and two failed attempts to introduce it, the tax seems likely to remain.

David Swinbanks

\title{
More yen for joint research
}

\section{Tokyo}

LEGISLAATION at present before Japan's Diet will allow the Science and Technology Agency to launch a new international programme in October to promote joint research with overseas institutions. The new programme will for the first time open a way for Japanese government money to be spent on research facilities in foreign countries.

The new research initiative will be modelled along the lines of the agency's Exploratory Research for Advanced Technology (ERATO) programme, which recently received high marks in an assessment by US researchers (see Nature 337, 196; 1989). ERATO, which is run by the agency's Research and Development Corporation of Japan (JRDC), finances 'high-risk' research with potential for application. Although some foreign scientists participate in ERATO, the research is carried out entirely within Japan. The new 'international ERATO' will allow participation by overseas research organizations (in government, industry and university) through cooperative research agreements. Legislation allowing JRDC to establish such agreements is expected to pass through the Diet within the next month or two, say agency officials.

The programme will support teams of about 20 researchers, about half based in Japan and half overseas, with funds of about $\$ 8$ to $\$ 13$ million for periods of 3 to 5 years. Agency officials hope that participating countries will contribute research funds and facilities as well as researchers, although it is possible that JRDC will 'rent' research laboratories overseas as the corporation now does in Japan for ERATO.

Until now, it has been almost impossible for Japanese government organizations to spend money on research facilities in foreign countries because of the lack of rules and mechanisms for auditing and accounting. A classic example is the bureaucratic delay encountered by Tokyo Astronomical Observatory in its attempts to build the world's largest telescope in Hawaii (see Nature 311, 5; 1984). After years of debate, the telescope has still to win government approval. By renting rather than buying research facilities, agency officials are confident they can avoid such problems.

Masahiko Noda of the agency's International Affairs Division says the programme received a favourable response in the United States last month when he visited various organizations, including the Office of Science and Technology Policy, the National Science Foundation, universities and non-profit research institutions. And Kaname Ikeda, director of the division, says a research project with the
United States could be set up within a few months using the new mechanisms created under the US-Japan Science and Technology Agreement signed last June.

But some difficulties may be encountered in trying to apply the ERATO model to the United States. ERATO projects are headed by senior Japanese scientists hand-picked by JRDC, an approach that runs counter to the open and competitive research system of the United States. And agency officials admit that they will probably have to adopt a more "flexible" approach in foreign countries than that used in Japan.

Apart from international joint research projects, the new organization in JRDC will administer the agency's new postdoctoral fellowship scheme for foreign researchers which began last year (see Nature 335, 287; 1988), and will provide accommodation, Japanese language training, counselling and information for overseas researchers working in Japan. The agency has set aside $¥ 418$ million $(\$ 3 \cdot 2$ million) for the programme in the second half of fiscal year 1989 and about $¥ 800$ million to build 50 homes for foreign researchers in Tsukuba Science City by 1991

David Swinbanks

\section{HIGHER EDUCATION}

\section{Vet schools reprieved in Britain}

\section{London}

FEARS that two of Britain's six veterinary schools may have to close receded last week when the Universities Funding Council decided to ask the Ministry of Agriculture, Fisheries and Food (MAFF) to reconsider future manpower requirements in the veterinary profession. A review is expected to show that previous forecasts of manpower needs were too low and that all six schools are necessary.

A report published in January recommended the closure of the veterinary schools at the Universities of Glasgow and Cambridge and the redistribution of their staff to the remaining four schools (see Nature 338, 191, 16 March 1989). But the British Veterinary Association now argues that more students are needed and that earlier estimates it gave to MAFF were wrong.

The decision was welcomed by James Armour, head of the veterinary school at the University of Glasgow. But he remains dissatisfied that the recommendation to close Glasgow was partly based on its proximity to Edinburgh, where there is another veterinary school, rather than solely on academic performance.

Christine McGourty 